\title{
Atypical and unusual clinical presentation of atopic dermatitis: A case report
}

\author{
Apresentação clínica atípica e incomum de dermatite atópica: relato de caso
}

\author{
Amanda Bertazzoli Diogo1, Isabella Silva De-Carvalho', Eduardo Sterman Campos", \\ Juliana Stracci ${ }^{1}$, Tatiana de Aguiar Tajra ${ }^{1}$
}

\section{ABSTRACT}

Atopic Dermatitis, also called atopic eczema, is a complex systemic inflammatory disease with heterogeneous clinical morphologies. Common features are eczematous lesions, intense pruritus and chronic or relapsing disease course. Eczematous lesions typically show an age-related distribution. However, this disease can present different phenotypes, like follicular/papular dermatitis and prurigo nodularis. We reported a male, 22 years old, phototype IV, African descent, with personal and familial history of atopy. He reported pruritus, xerosis and lesions on skin since he was 2 years-old, with relapsing and chronic course. Clinical examination showed disseminated perifollicular accentuation and rough follicular papules. Extensor surfaces of the legs showed excoriated papules and nodules, beside generalized post-inflammatory hypopigmentation. He had lichenified plaques on the back, neck, hands and foot. Skin biopsy showed spongiosis, parakeratosis and irregular acanthosis at the epidermis. The diagnosis was late and occurred only in adulthood. Due to the extensive and relapsing presentation, he received Cyclosporin $3 \mathrm{mg} / \mathrm{Kg} /$ day, associated to steroids and emollients, with improvement of pruritus, xerosis and lechinification. But he maintained perifollicular accentuation. The patient presented common features of Atopic Dermatitis, like chronic and relapsing lesions, history of atopic, dry skin, pruritus, and early disease onset. However, atypical morphologies were presented, exemplified by prurigo nodularis and follicular/papular dermatitis. Other relevant finding it was the fact that the lesions occurred outside the classic areas, with prevalence on extensor surfaces and trunk. These atypical morphologies and unusual location of lesions are prevalent on adults with high phototypes, as seen in this case. It is essential to identify these challenging phenotypes, because the diagnosis of Atopic Dermatitis is clinical. Given the diversity of clinical presentation and difficult to recognize some cases, this article will contribute to demonstrate atypical manifestations and common features in non-white patients, facilitating correct diagnosis and early treatment.

Keywords: Atopic dermatitis, phenotype, african americans, skin diseases, clinical diagnosis.

\section{RESUMO}

A dermatite atópica, também chamada de eczema atópico, é uma doença inflamatória sistêmica complexa, com morfologias clínicas heterogêneas. As características comuns são lesões eczematosas, prurido intenso e curso crônico ou recidivante. Lesões eczematosas geralmente mostram uma distribuição relacionada à idade. No entanto, essa doença pode apresentar diferentes fenótipos, como dermatite folicular/papular e prurigo nodular. Relatamos um homem, 22 anos, fototipo IV, afrodescendente, com história pessoal e familiar de atopia. Referia prurido, xerose e lesões na pele desde os 2 anos, com recidiva e curso crônico. O exame clínico mostrou acentuação perifolicular disseminada e pápulas foliculares ásperas. As superfícies extensoras das pernas apresentavam pápulas e nódulos escoriados, além de hipopigmentação pós-inflamatória generalizada. Notaram-se placas liquenificadas no dorso, pescoço, mãos e pés. A biópsia de pele demonstrou espongiose, paraqueratose e acantose irregular na epiderme. $\mathrm{O}$ diagnóstico foi tardio e ocorreu apenas na idade adulta. Devido ao quadro clínico extenso e recidivante, recebeu Ciclosporina $3 \mathrm{mg} / \mathrm{Kg} / \mathrm{dia}$, associada a esteroides e emolientes, com melhora de prurido, xerose e liquenificação, mas manteve a acentuação perifolicular. O paciente apresentava características comuns de dermatite atópica, como lesões crônicas e recidivantes, história de atopia, pele seca, prurido e início precoce da doença, no entanto, foram apresentadas morfologias atípicas, exemplificadas por prurigo nodular e dermatite folicular/papular. Outro achado relevante foi o fato das lesões localizarem-se em áreas não clássicas da doença, com predomínio nas superfícies extensoras e tronco. Essas morfologias atípicas e localizações incomuns são prevalentes em adultos com fototipos elevados, como visto neste caso. É essencial identificar esses fenótipos desafiadores, porque o diagnóstico de dermatite atópica é clínico. Devido à diversidade de apresentações clínicas e dificuldade de reconhecimento de alguns casos, este artigo contribuirá para demonstrar manifestações atípicas e características comuns em pacientes não brancos.

Descritores: Dermatite atópica, fenótipo, afro-americanos, dermatopatias, diagnóstico clínico.

1. Centro Universitário São Camilo, Disciplina de Dermatologia - São Paulo, SP, Brazil.

Submitted: 09/16/2021, accepted: 11/10/2021.

Arq Asma Alerg Imunol. 2021;5(4):437-41.

http://dx.doi.org/10.5935/2526-5393.20210066 


\section{Introduction}

Atopic Dermatitis (AD), also called atopic eczema, is a complex systemic inflammatory disease with heterogeneous clinical morphologies.1,2 Essential features are eczematous lesions, intense pruritus and chronic or relapsing disease course. Eczematous lesions typically show an age-related distribution. Infants often present with acute lesions characterized by poorly defined erythema with oedema, vesicles, excoriations and serous exudate on the face, cheeks and trunk. In childhood, eczema becomes chronic (lichenification), commonly affecting flexor surfaces. ${ }^{1}$ In adolescent and adult, often lichenified and excoriated plaques are found, particularly at flexures. ${ }^{2}$ Hands and feet become a concerning focus for atopic dermatitis. $^{3}$

However, this disease can present different morphologies, like follicular/papular dermatitis and prurigo nodularis. ${ }^{1-3}$ These atypical forms are difficult to recognize, with prevalence on adults with high phototypes. $^{1}$

There are several genes associated with AD, depending on the ethnicity. For example, the association between Filaggrin mutations and $A D$ is less clear in people of African ancestry. This finding may explain some clinical features more common on this type of patient. Given the race specific genetic polymorphism associated with $A D$, particularly with regard to the Filaggrin mutations, there are likely differences in epidermal structure among ethnic groups. Some studies suggesting a lower rate of transepithelial water loss in African American, despite an overall greater severity of this disease on this group. Patients of African descent less commonly develop flexural dermatitis, being more common the involvement of the extensor surfaces. Perifollicular accentuation and scattered papules on the extensor and trunk are also more common in darker skin. This type of skin favors the development of post inflammatory dyspigmentation. ${ }^{3}$ Moreover, in terms of disease severity, studies have found that African Americans tend to have greater AD severity compared with whites. 3,4

The AD diagnosis is clinical and there are many criteria that try to reach all forms of presentation, like Hanifin and Rajka diagnostic. However, the recognition of atypical presentations of $A D$ is challenging, because they do not present accurate criteria. 4,5

\section{Case presentation}

Male, 22-Year-old, natural from São Paulo (Brazil), phototype IV, African descent, with personal history of rhinitis and asthma, besides family history of atopic dermatitis. He reported pruritus, xerosis and lesions on skin since he was 2 years-old, with relapsing and chronic course. Initially, the lesions were localized on the cubital and popliteal fossae. At 8, this eczema evolved to current locations. The patient received multiple diagnosis, like pityriasis rubra pilaris and generalized keratosis pilaris. He previously used topic steroids and emollients, with no improvement.

Clinical examination revealed intensely dry skin and diffuse lichenification. The main feature observed was the disseminated perifollicular accentuation. The skin demonstrated widespread rough follicular papules, post-inflammatory hypopigmentation (Figures 1 and 2), beside severe lichenified plaques on the back, neck, hands and foot (Figures 3 and 4). Extensor surfaces of the legs showed excoriated papules and nodules (Figure 5). On the face, we noticed Dennie - Morgan fold.

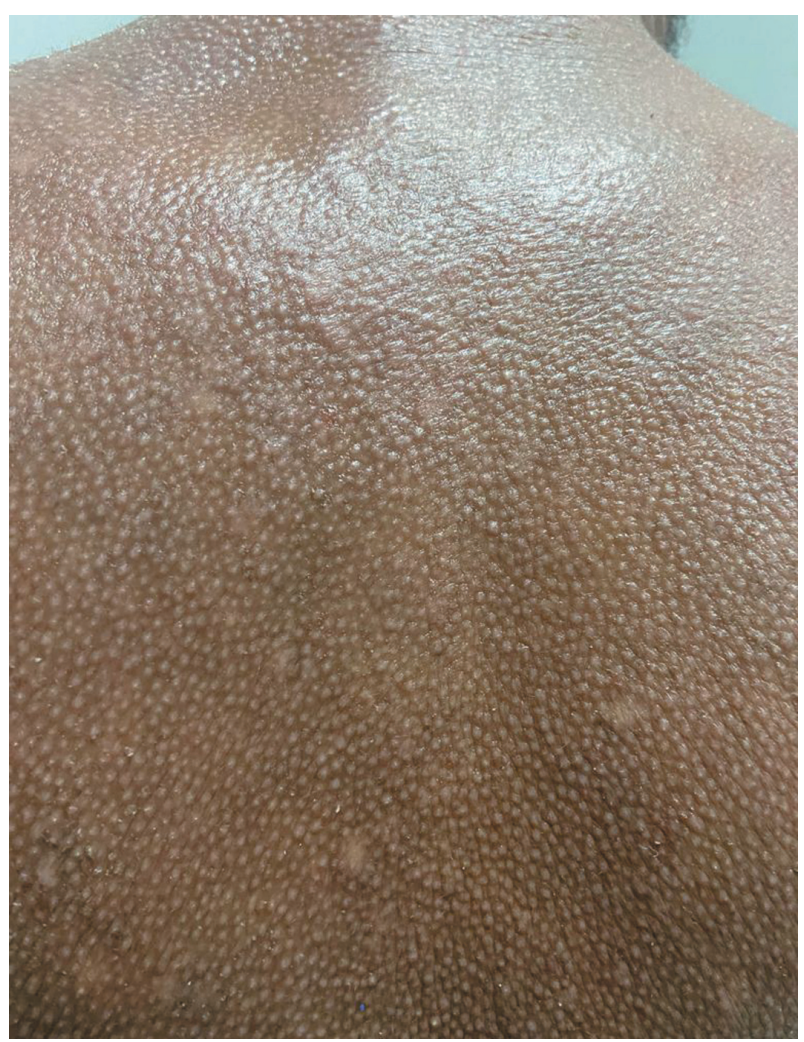

Figure 1

Skin lesions on the back: perifollicular accentuation, rough papules and post-inflammatory hypopigmentation 


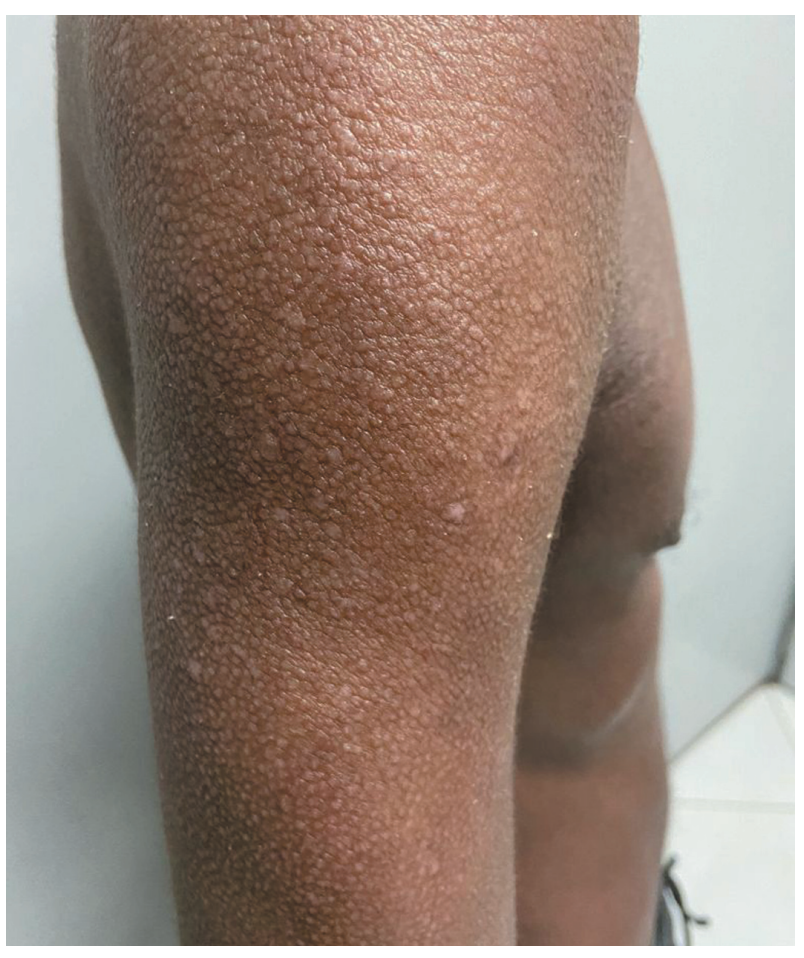

Figure 2

Skin lesions on the extensor surface of the upper limb: perifollicular accentuation, rough papules and post-inflammatory hypopigmentation

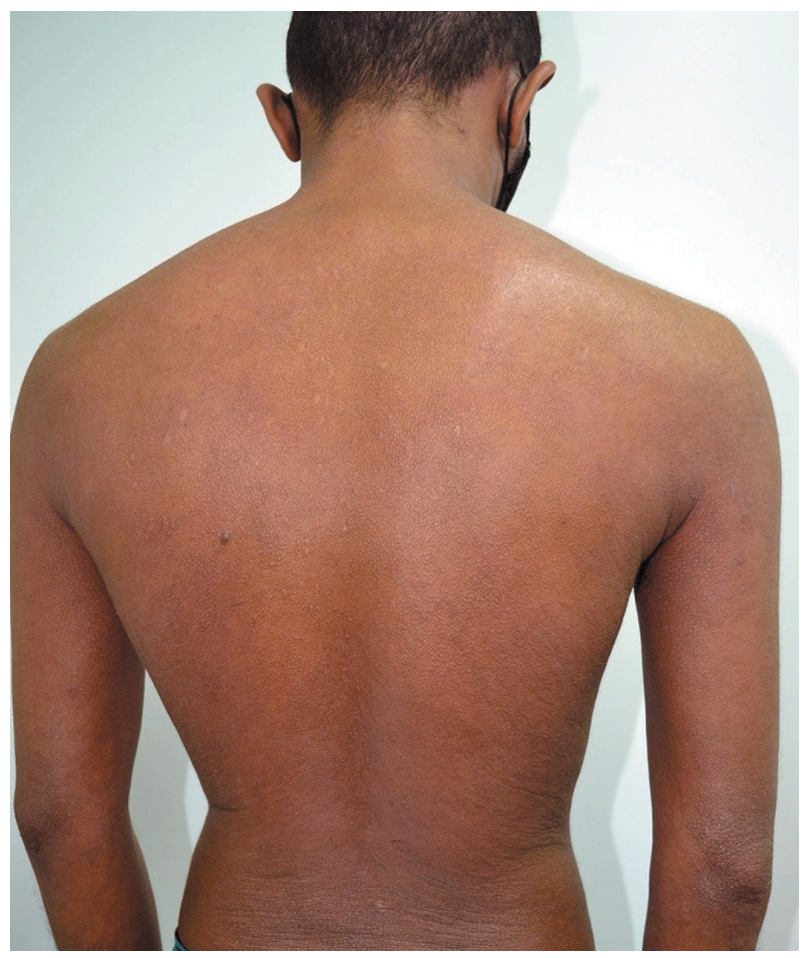

Figure 3

Skin lesions widespread on the back: perifollicular accentuation, rough papules, post-inflammatory hypopigmentation and lichenified plaques

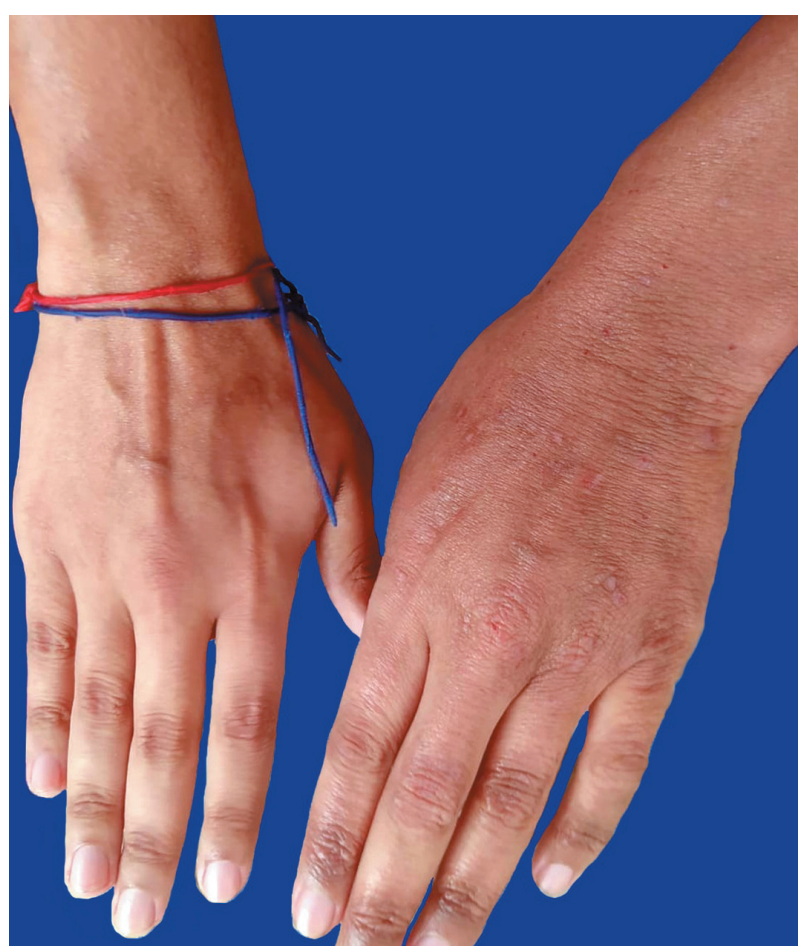

Figure 4

Hand eczema: lichenified plaques on the back of left hand

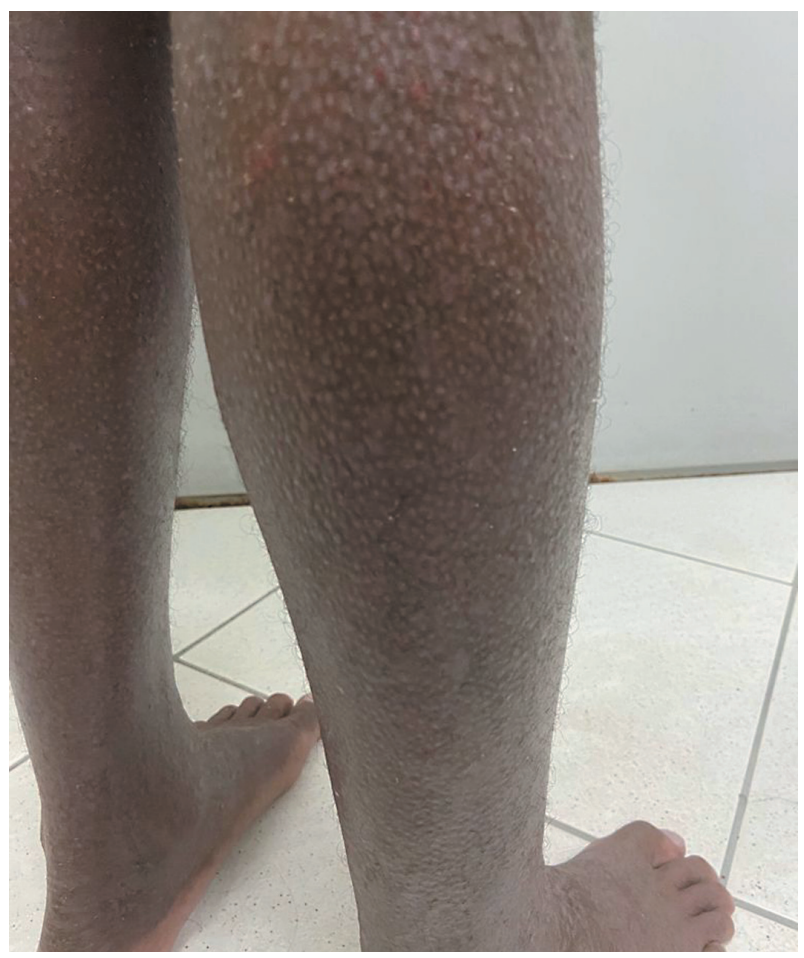

\section{Figure 5}

Extensor surfaces of the legs shows xerosis, excoriated papules, perifollicular accentuation, rough papules 
The skin biopsy was performed, that showed spongiosis, parakeratosis and irregular acanthosis at the epidermis (Figure 6). The dermis demonstrated papillary fibroplasia, verticalization of collagen fibers and perivascular infiltrates dominated by lymphocytes and eosinophils. These findings were compatible of $A D$.

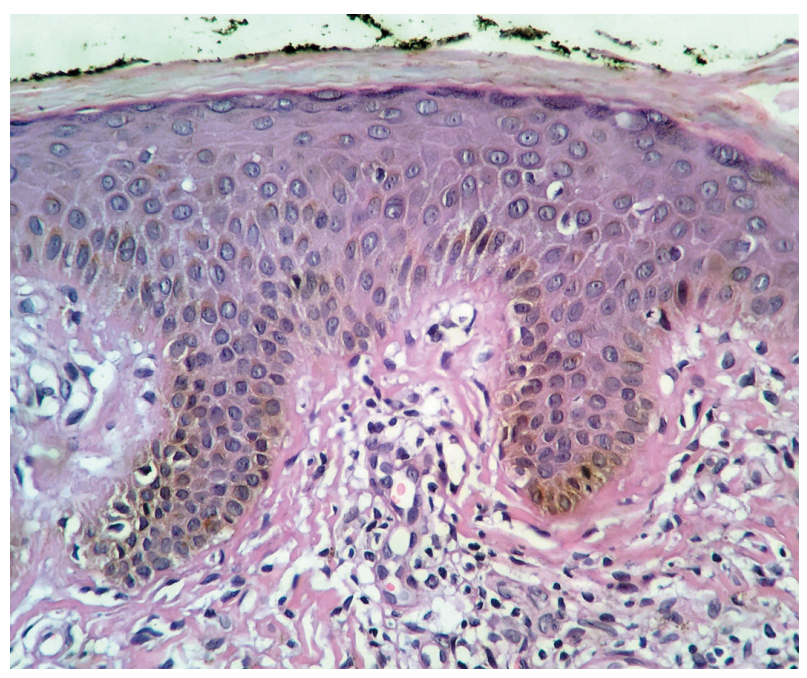

Figure 6

The skin biopsy showed spongiosis, parakeratosis and irregular acanthosis

Blood laboratory analysis revealed eosinophilia (790/microliter), increased levels of total Immunoglobulin $\mathrm{E}(1.000 \mathrm{IU} / \mathrm{ml})$ and high serum specific Immunoglobulin E to house dust - mite (3,5 $\mathrm{kU} / \mathrm{l})$. We performed patch testing with Brazilian standard series (Immunotech Company ${ }^{\mathrm{TM}}$ ), that showed strong positivity to nickel sulfate $(+++)$.

Based on anamnesis and clinical characteristics, the patient received the diagnosis of $A D$, that was late and occurred only in adulthood.

Due to the extensive and relapsing presentation, he received Cyclosporin $3 \mathrm{mg} / \mathrm{Kg} /$ day, associated to steroids and emollients, with improvement of pruritus, xerosis and eczematous lesions. But he maintained perifollicular accentuation.

\section{Discussion}

The patient presented common features of $A D$, like chronic and relapsing lesions, history of atopic, dry skin, pruritus and early disease onset.

However, atypical morphologies were presented, exemplified by prurigo nodularis and follicular/papular dermatitis, both intensely itchy. Other relevant finding was the fact that these lesions less commonly developed on classical flexural areas, being more prevalent on the extensor surfaces and trunk.

These atypical morphologies and unusual location of lesions are more common on adults with high phototypes, ${ }^{3,4}$ as seen in this case.

Follicular/papular eczema is commonly observed on the extensors and trunk, ${ }^{3,4}$ like noticed in this case, instead of the classic flexural involvement, in adults. ${ }^{1-3}$

Besides this, the prurigo nodularis, represented by excoriated papules and nodules, is also more prevalent in non-classic areas of $A D$, mainly on the extensor surfaces, ${ }^{1}$ as seen in this article.

The patient showed important post-inflammatory dyspigmentation. This is common in patients of darker skin color, ${ }^{3,4}$ like noticed in this case.

Other classic findings in high phototypes include diffuse xerosis and Dennie-Morgan fold, being both features presented on this report.

Another important aspect was the presence of lichenified plaques on the neck, hand and foot. This type of lesions are minor criteria of Hanifin and Rajka's diagnostic and are more common on adults, ${ }^{4,5}$ as observed on this article.

Previous studies also observed that African Americans patients have a higher tendency to present with prurigo nodularis and lichenification than other ethnic groups, ${ }^{3,5}$ being these findings observed on this report.

Some aspects difficulted the diagnosis of $A D$ in our patient. The first is related to poor recognition of the erythema, due to dark skin. This can present a challenge to make the diagnosis and assessing the severity of $A D$.

Erythema is a feature that is included in several scoring tools, like Scoring Atopic Dermatitis and Eczema Area and Severity Index. Erythema on darker skin is more likely to appear violaceous or may be missed completely. ${ }^{3,4}$ 
Second, the atypical localization of lesions, that occurred mainly on the extensor surface, back and chest.

Third, related to morphologic variant, with the follicular/papular and prurigo patterns being the main phenotypes.

It is essential to identify these challenging patterns because the diagnosis of $A D$ is clinical. ${ }^{4,5}$

Given the diversity of clinical presentation and difficult to recognize some cases, this article will contribute to demonstrate atypical manifestations and common features in non-white patients with $A D$, facilitating correct diagnosis and early treatment.

\section{References}

1. Girolomoni G, Bruin-Weller M, AokiV, Kabashima K, Deleuran M, Puig L, Bansal A, et al. Nomenclature and clinical phenotypes of atopic dermatitis. Ther Adv Chronic Dis. 2021;12:20406223211002979.
2. Langan SM, Irvine AD, Weidinger S. Atopic Dermatitis. Lancet. 2020;396:34-60.

3. Kaufman BP, Yassky EG, Alexis AF. Atopic dermatitis in diverse racial and ethnic groups - Variations in epidemiology, genetics, clinical presentation and treatment. Exp Dermatol. 2018;27:340-57.

4. Yong AMY, Tay YK. Atopic Dermatitis: Racial and Ethnic Differences. Dermatol Clin. 2017;35:395-402.

5. Silverberg NB. Typical and atypical clinical appearance of atopic dermatitis. Clin Dermatol. 2017;35:354-9.

No conflicts of interest declared concerning the publication of this article.

Corresponding author:

Amanda Bertazzoli Diogo

E-mail: amanda.diogo@prof.saocamilo-sp.br 